\title{
Density Functional Theory Investigation into the B and Ga Doped Clean and Water Covered $\gamma$-Alumina Surfaces
}

\author{
Lihong Cheng, ${ }^{1}$ Tianliang Xu, ${ }^{2}$ Wenkui Li, ${ }^{1}$ Zhiqin Chen,, Jianping Ai, \\ Zehua Zhou, ${ }^{1}$ and Jianwen Liu $^{3}$ \\ ${ }^{1}$ Key Laboratory of Surface Engineering of Jiangxi Province, Jiangxi Science and Technology Normal University, \\ Nanchang, Jiangxi 330013, China \\ ${ }^{2}$ Zhengzhou Institute of Finance and Economics, Zhengzhou, China \\ ${ }^{3}$ National Supercomputing Center in Shenzhen, Shenzhen 518055, China \\ Correspondence should be addressed to Lihong Cheng; chenglihong001@126.com and Jianwen Liu; liujw@nsccsz.gov.cn
}

Received 15 February 2017; Accepted 15 March 2017; Published 26 April 2017

Academic Editor: Tao Wang

Copyright (C) 2017 Lihong Cheng et al. This is an open access article distributed under the Creative Commons Attribution License, which permits unrestricted use, distribution, and reproduction in any medium, provided the original work is properly cited.

\begin{abstract}
The structures and energies of the B and Ga incorporated $\gamma$-alumina surface as well as the adsorption of water are investigated using dispersion corrected density functional theory. The results show that the substitution of surface $\mathrm{Al}$ atom by $\mathrm{B}$ atom is not so favored as $\mathrm{Ga}$ atom. The substitution reaction prefers to occur at the tricoordinated $\mathrm{A}(4)$ sites. However, the substitution reaction becomes less thermodynamically favored when more $\mathrm{Al}$ atoms are substituted by $\mathrm{B}$ and $\mathrm{Ga}$ atoms on the surface. Moreover, the substitution of bulk $\mathrm{Al}$ atoms is not so favored as the $\mathrm{Al}$ atoms by $\mathrm{B}$ and $\mathrm{Ga}$ on the surface. The $\gamma$-alumina surface is found to have stronger adsorption ability for water than the $\mathrm{B}$ and $\mathrm{Ga}$ incorporated surface. The total adsorption energy increases as water coverage increases, while the stepwise adsorption energy decreases. The studies show the coverage of water at $7.5 \mathrm{H}_{2} \mathrm{O} / \mathrm{nm}^{2}$ (five $\mathrm{H}_{2} \mathrm{O}$ molecules per unit cell) can fully cover the active sites and the further water molecule could only be physically adsorbed on the surface.
\end{abstract}

\section{Introduction}

The $\gamma$-alumina is an important material in chemistry and materials science due to its widespread applications in chemical industry [1-3], ceramics, and semiconductors [4-7]. In order to improve the performance of the material, some heteroatoms were usually chosen to be incorporated into the $\gamma$-alumina bulk and surfaces $[8,9]$. For example, the Fe atom was usually used to improve the catalytic performance of $\gamma$-alumina [10]. Wan et al. investigated the $\mathrm{Fe}_{2} \mathrm{O}_{3} / \mathrm{Al}_{2} \mathrm{O}_{3}$ catalyst from coprecipitated and spray-dried method with Mösbauer spectroscopy [11] and found the reduction of $\mathrm{Fe}_{2} \mathrm{O}_{3}$ to $\mathrm{FeO}$. The substitution of surface $\mathrm{Al}^{3+}$ by $\mathrm{Fe}^{3+}$ in alumina with mixed $\left(\mathrm{Al}_{1-x} \mathrm{Fe}_{x}\right)_{2} \mathrm{O}_{3}$ surface formation is also confirmed by transmission Mösbauer spectroscopy. Integral low-energy electron Mösbauer spectroscopy and $\mathrm{Fe}$ $\mathrm{K}$-edge X-ray absorption near-edge structure characterization observed the formation of iron nanoclusters from the transformation of $\gamma-\left(\mathrm{Al}_{1-x} \mathrm{Fe}_{x}\right)_{2} \mathrm{O}_{3}$ to $\alpha-\left(\mathrm{Al}_{1-x} \mathrm{Fe}_{x}\right)_{2} \mathrm{O}_{3}$ and the iron distribution on the surface layers and in the cores of grains [12-14]. This field also attracts the interests of theoretical researches. Feng et al. calculated the structures and energies of the Fe promoted $\gamma$-alumina surface [10] and found that the incorporation of Fe atom into the $\gamma$-alumina surface is possible, while it is thermodynamically not so favored for the $\mathrm{Fe}$ substitution for the bulk $\mathrm{Al}$ atoms. The adsorption of water on the $\gamma$-alumina surface is stronger than that on the $\mathrm{Fe}_{2} \mathrm{O}_{3}$ covered surface. In addition, the electronic structures also change after the substitution of the $\mathrm{Al}$ atoms by the Fe atoms on the surface. Except for the incorporation of Fe into the alumina surface, the B and Ga atoms, which are often used as the trivalent substitution ions for the zeolites $[15,16]$, are also used in experiments for the preparation of high performance catalysis and semiconductors $[8,9$, 17-19]. Kibar et al. prepared nanostructured boron doped alumina catalyst support [20] and found that the morphology of the supports can be modified from cracked surface to nanosphere formation by the introduction of boron. Jansons 
et al. introduced Ga into the alumina crystal and prepared a new complex luminescence band at about $5 \mathrm{eV}$ [19]. The Garelated luminescence can be observed under the excitation of X-rays up to $600 \mathrm{~K}$. In order to know the energies as well as the structures of the B and Ga incorporated $\gamma$-alumina surface at molecular level, the present work investigated the thermodynamic and structure properties of the $\mathrm{B}$ and $\mathrm{Ga}$ incorporated $\gamma$-alumina surface using dispersion corrected periodic density functional theory. Since $\gamma$-alumina is usually prepared and used in atmospheres containing water, the adsorption of water on the B and Ga incorporated $\gamma$-alumina is also investigated and compared with the water adsorption on pure $\gamma$-alumina surface.

\section{Computational Details}

The dispersion-corrected periodic density functional as implemented in the Vienna ab initio Simulation Package (VASP) was used for the calculations [21-23]. The DFTD3 method of Grimme was used to take into account the dispersive interactions as previous work reported that the dispersion correction seriously influences the relative stability order and adsorption energies [24-28]. The exchange and correlation energies were calculated by the generalized gradient approximation (GGA) formulation with the $\mathrm{PBE}$ functional [21]. The Kohn-Sham one-electron states were extended in accordance with plane-wave basis sets with a kinetic energy of $400 \mathrm{eV}$. The projector augmented wave (PAW) method was applied to describe the electron-ion interactions [29-31].

The Brillouin zone was sampled with $5 \times 5 \times 5$ and $3 \times 3 \times$ $1 k$-points meshes generated by the Monkhorst-Pack algorithm, for the $p(1 \times 1 \times 1) \gamma$-alumina cell and $p(1 \times 1) \gamma$-alumina (110) surface slab, respectively. The convergence criteria were set to be $10^{-4} \mathrm{eV}$ for the SCF energy, $10^{-3} \mathrm{eV}$ and $0.03 \mathrm{eV} / \AA$ for the total energy and the atomic forces, respectively.

The $\gamma$-alumina surface was described using the Digne's model [32], and (110) surface was taken into account. As shown in Figure 1, $\gamma$-alumina surface was modeled using a $p(1 \times 1)$ supercell with an eight-layer slab, which contains sixteen $\mathrm{Al}_{2} \mathrm{O}_{3}$ units. A vacuum with thickness of $15 \AA$ was employed to separate each slab from interactions. The top four layers and the adsorbates were fully relaxed, and the bottom four layers were fixed in their bulk position during the structure optimization. In order to facilitate the discussions, the surface layer $\mathrm{Al}$ and $\mathrm{O}$ atoms are indexed with number. The coordination number of each $\mathrm{Al}$ atom was expressed by subscript. As has been described in many previous works $[33,34]$, the $\mathrm{Al}$ atoms in bulk $\gamma$-alumina are in tetrahedral and octahedron sites. After cleavage, the tetrahedral and octahedron $\mathrm{Al}$ atoms expose as the tricoordinated and tetracoordinated Al, respectively, in the (110) surface. As shown in Figure 1, the $\mathrm{Al}(4)_{3 \mathrm{c}}$ was in tetrahedral site in the bulk, and $\mathrm{Al}(1)_{4 \mathrm{c}}, \mathrm{Al}(2)_{4 \mathrm{c}}$, and $\mathrm{Al}(3)_{4 c}$ were in octahedral sites in the bulk. It could be observed from the top view that $\mathrm{Al}(1)$ and $\mathrm{Al}(2)$ atoms are in the same chemical environment.

For the substitution of surface $\mathrm{Al}^{3+}$ by $\mathrm{X}^{3+}(\mathrm{X}=\mathrm{B}$ and $\mathrm{Ga}$ ) in reaction (1) the substitution energy is defined as $E_{\text {sub }}=$ $n E\left[\mathrm{Al}(\mathrm{OH})_{3}\right]+E\left[\mathrm{Al}_{(4-n)} \mathrm{X}_{n} \mathrm{O}_{6}{ }^{*}\right]-n E\left[\mathrm{X}(\mathrm{OH})_{3}\right]-E\left[\mathrm{Al}_{4} \mathrm{O}_{6}{ }^{*}\right]$, where $E\left[\mathrm{X}(\mathrm{OH})_{3}\right]$ and $E\left[\mathrm{Al}_{4} \mathrm{O}_{6}{ }^{*}\right]$ present the energies of the gas phase $\mathrm{X}(\mathrm{OH})_{3}$ and the isolated oxide surfaces $(*$ presents the 2-8 layers alumina substrate), respectively. The positive substitution energy means substitution reaction is not thermodynamically favored.

$$
n \mathrm{X}(\mathrm{OH})_{3}+\mathrm{Al}_{4} \mathrm{O}_{6}{ }^{*} \longrightarrow n \mathrm{Al}(\mathrm{OH})_{3}+\mathrm{Al}_{(4-n)} \mathrm{X}_{n} \mathrm{O}_{6}{ }^{*} \text {. }
$$

The adsorption energy of $n \mathrm{H}_{2} \mathrm{O}(n=1-6)$ on the oxide surface was defined as $E_{\mathrm{ads}}=E\left[\left(\mathrm{H}_{2} \mathrm{O}\right)_{n} \cdot \mathrm{X}_{4} \mathrm{O}_{6}{ }^{*}\right]-n E\left(\mathrm{H}_{2} \mathrm{O}\right)-$ $E\left(\mathrm{X}_{4} \mathrm{O}_{6}{ }^{*}\right)$, where $E\left[\left(\mathrm{H}_{2} \mathrm{O}\right)_{n} \cdot \mathrm{X}_{4} \mathrm{O}_{6}{ }^{*}\right], E\left(\mathrm{H}_{2} \mathrm{O}\right)$, and $E\left(\mathrm{X}_{4} \mathrm{O}_{6}{ }^{*}\right)$ are the total energies of the minima structures of $\mathrm{X}_{4} \mathrm{O}_{6}{ }^{*}(\mathrm{X}=$ $\mathrm{B}, \mathrm{Al}, \mathrm{Ga})$ surface with adsorbed water, gas phase water molecule, and clean $\mathrm{X}_{4} \mathrm{O}_{6}{ }^{*}$ surface, respectively. Following this definition, a more negative value indicates stronger interaction between adsorbed species and the surface.

$$
n \mathrm{H}_{2} \mathrm{O}+\mathrm{X}_{4} \mathrm{O}_{6}^{*} \longrightarrow\left(\mathrm{H}_{2} \mathrm{O}\right)_{n} \mathrm{X}_{4} \mathrm{O}_{6}{ }^{*}
$$

\section{Results and Discussion}

3.1. Substitution of $A l$ by $B$ and $G a$ on the Surface. Table 1 shows the substitution energies for the substitution of $\mathrm{Al}$ by $\mathrm{B}$ and $\mathrm{Ga}$ on the surface. As indicated by the calculated substitution energies, the substitution of surface $\mathrm{Al}$ by $\mathrm{B}$ atoms is not thermodynamically favored, since the calculated substitution energies are positive. The tricoordinated $\mathrm{Al}(4)$ is the most favored site for one $\mathrm{B}$ incorporation with the substitution energy of $1.31 \mathrm{eV}$. The tetracoordinated $\mathrm{Al}(1)$ and $\mathrm{Al}(3)$ sites are slightly difficult with the substitution energies of 1.81 and $2.29 \mathrm{eV}$, respectively.

For two $\mathrm{Al}$ atoms substituted by $\mathrm{B}$ atoms on the surface, which corresponds to $50 \%$ surface, $\mathrm{Al}$ were replaced by $\mathrm{B}$; the $\mathrm{Al}(1,2)$ are the most favored, with the substitution energy of $3.22 \mathrm{eV}$, versus $\mathrm{Al}(1,2,3)$ for $75 \%$ surface $\mathrm{Al}$ substitution by $\mathrm{B}$, with the substitution energy of $5.32 \mathrm{eV}$. The substitution energies positively increase to $7.82 \mathrm{eV}$ as all surface $\mathrm{Al}$ atoms were substituted by B atoms.

Figure 2 shows the structures for the B and Ga substituted $\gamma$-alumina surface. The corresponding bond distances of the surface layer atoms before and after the substitution are given in Table 1. It is found that the surface Al-O bond distances are in the range of 170-186 pm on the $\gamma$-alumina surface. After the substitution of $\mathrm{Al}$ by $\mathrm{B}$ atoms, the $\mathrm{Al}-\mathrm{O}$ bond distance almost remains the same. It should be noted that the $\mathrm{B}-\mathrm{O}$ bond distances (137-167 pm) are much shorter than those of the $\mathrm{Al}-\mathrm{O}$ bonds, since the radius of $\mathrm{B}$ atom is much shorter than that of $\mathrm{Al}$ [35]. In addition, the $\mathrm{B}$ atom prefers to be tricoordinated, for example, for $\mathrm{B}(1,2,3,4)$ in Figure 2, bond e is elongated to $255 \mathrm{pm}$ and became broken.

Since the substitution energies for the substitution of $\mathrm{Al}$ by $\mathrm{Ga}$ are much less than those for $\mathrm{B}$ substitution, the $\mathrm{Ga}$ could be more easily incorporated into to the alumina surface than B. Particularly for the $\mathrm{Ga}(4)$ structure, the substitution energy is $-0.06 \mathrm{eV}$, which indicates the substitution reaction at $\mathrm{Al}(4)$ site by $\mathrm{Ga}$ is thermodynamically favored. Similar to that of B substitution, the substitution energy increases as more $\mathrm{Al}$ atoms were replaced by $\mathrm{Ga}$ atoms, for example, the substitution energies are $0.11,0.49$, and $0.90 \mathrm{eV}$, respectively, 
TABLE 1: Substitution energies $\left(E_{\text {sub }}\right)$ and the M-O bonds distances $(\mathrm{pm})$ of the surface layer atoms before and after substitution for B and Gain $\gamma$-alumina (110) surface.

\begin{tabular}{|c|c|c|c|c|c|}
\hline Substituted sites & $E_{\text {sub }}(\mathrm{eV})$ & $\mathrm{M}(1)-\mathrm{O}, \mathrm{a}-\mathrm{d}^{\mathrm{a}}$ & $\mathrm{M}(2)-\mathrm{O}, \mathrm{e}-\mathrm{h}^{\mathrm{a}}$ & $\mathrm{M}(3)-\mathrm{O}, \mathrm{i}-1^{\mathrm{a}}$ & $\mathrm{M}(4)-\mathrm{O}, \mathrm{m}-\mathrm{O}^{\mathrm{a}}$ \\
\hline$\gamma$-alumina & & $174,185,173,182$ & $185,174,173,182$ & $186,186,180,170$ & $180,171,171$ \\
\hline $\mathrm{B}(1)$ & 1.81 & $141,225,137,145$ & $183,176,172,183$ & $184,187,179,169$ & $181,175,171$ \\
\hline $\mathrm{B}(3)$ & 2.29 & $173,185,172,182$ & $185,173,172,182$ & $167,167,149,138$ & $181,171,171$ \\
\hline $\mathrm{B}(4)$ & 1.31 & $173,183,177,185$ & $183,173,177,185$ & $185,185,181,171$ & $149,139,139$ \\
\hline $\mathrm{B}(1,2)$ & 3.22 & $142,232,136,145$ & $232,142,136,145$ & $186,186,178,169$ & $188,176,176$ \\
\hline $\mathrm{B}(2,3)$ & 3.94 & $175,182,173,184$ & $227,141,137,145$ & $147,218,145,136$ & $181,171,176$ \\
\hline $\mathrm{B}(2,4)$ & 3.58 & $175,191,174,183$ & $166,145,146,155$ & $184,185,181,170$ & $147,138,142$ \\
\hline $\mathrm{B}(3,4)$ & 3.70 & $172,182,177,185$ & $182,172,177,185$ & $164,164,151,139$ & $150,139,139$ \\
\hline $\mathrm{B}(1,2,3)$ & 5.32 & $141,235,136,145$ & $235,141,136,145$ & $165,165,149,138$ & $188,177,177$ \\
\hline $\mathrm{B}(1,2,4)$ & 6.02 & $145,188,142,151$ & $188,145,142,151$ & $184,184,181,170$ & $146,141,141$ \\
\hline $\mathrm{B}(2,3,4)$ & 5.81 & $174,191,175,184$ & $167,145,147,155$ & $146,250,146,136$ & $147,138,142$ \\
\hline $\mathrm{B}(1,2,3,4)$ & 7.82 & $146,151,146,161$ & $255,140,138,144$ & $163,162,152,138$ & $145,139,142$ \\
\hline $\mathrm{Ga}(1)$ & 0.39 & $183,200,179,191$ & $184,174,172,182$ & $186,185,180,170$ & $179,172,171$ \\
\hline $\mathrm{Ga}(3)$ & 0.17 & $174,185,173,182$ & $185,174,173,182$ & $200,200,186,175$ & $180,171,171$ \\
\hline $\mathrm{Ga}(4)$ & -0.06 & $174,185,173,182$ & $185,174,173,182$ & $186,186,180,170$ & $188,179,179$ \\
\hline $\mathrm{Ga}(1,2)$ & 0.82 & $182,198,179,191$ & $198,182,179,191$ & $186,186,180,170$ & $178,172,172$ \\
\hline $\mathrm{Ga}(2,3)$ & 0.57 & $174,184,173,182$ & $200,183,180,191$ & $199,200,186,176$ & $179,171,172$ \\
\hline $\mathrm{Ga}(2,4)$ & 0.31 & $174,184,173,181$ & $200,183,180,191$ & $185,186,180,170$ & $187,179,177$ \\
\hline $\mathrm{Ga}(3,4)$ & 0.11 & $174,185,173,182$ & $185,174,173,182$ & $200,200,186,175$ & $188,179,179$ \\
\hline $\mathrm{Ga}(1,2,3)$ & 1.00 & $183,198,179,191$ & $198,183,179,191$ & $199,199,186,176$ & $178,172,172$ \\
\hline $\mathrm{Ga}(1,2,4)$ & 0.72 & $183,198,180,191$ & $198,183,180,191$ & $186,186,179,170$ & $186,180,180$ \\
\hline $\mathrm{Ga}(2,3,4)$ & 0.49 & $174,184,173,181$ & $200,183,181,191$ & $199,200,186,175$ & $187,179,181$ \\
\hline $\mathrm{Ga}(1,2,3,4)$ & 0.90 & $183,198,180,190$ & $198,183,180,190$ & $199,199,186,176$ & $186,180,180$ \\
\hline
\end{tabular}

${ }^{\mathrm{a}}$ Corresponding to Figure 1(c).

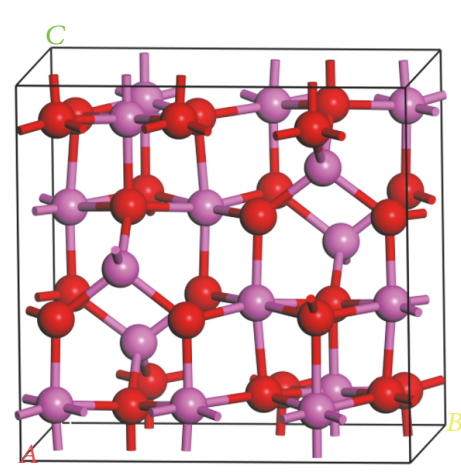

(a)

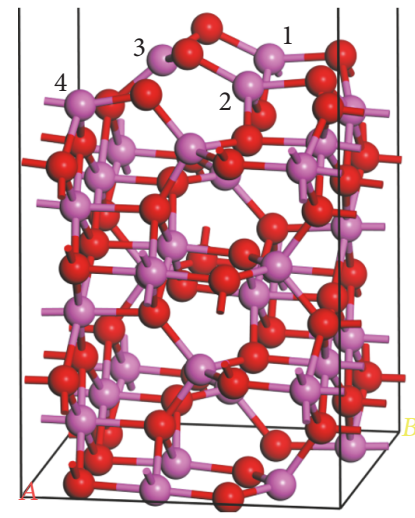

(b)

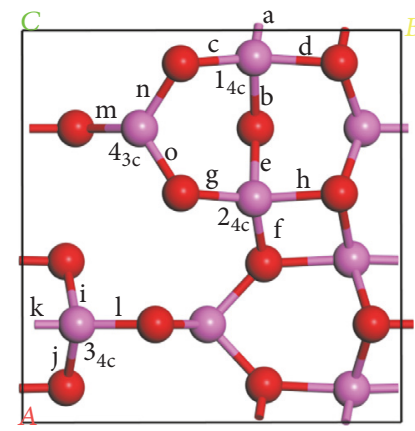

(c)

FIgURE 1: Side view of unit cell of $\gamma-\mathrm{Al}_{2} \mathrm{O}_{3}$ (a) and side (b) and top (c) views of the $\gamma-\mathrm{Al}_{2} \mathrm{O}_{3}(110)$ surface ( $\mathrm{Al}$ and $\mathrm{O}$ atoms are in rose and red, respectively. Coordination numbers of surface atoms are shown in subscript in (c)).

for $\mathrm{Ga}(3,4), \mathrm{Ga}(1,2,4)$, and $\mathrm{Ga}(1,2,3,4)$. Since the $\mathrm{Ga}$ atom radius is larger than that of $\mathrm{Al}$ [35], the $\mathrm{Ga}-\mathrm{O}$ bond distance is much longer than that of $\mathrm{Al}-\mathrm{O}$ bond distance. In order to map out whether it is possible for B and Ga substitution for the bulk $\mathrm{Al}$ atoms of $\gamma$-alumina, we also calculated the substitution energies for the substitution of the sublayer hexa- and tetracoordinated $\mathrm{Al}$ atom by $\mathrm{B}$ and $\mathrm{Ga}$ atoms. The calculated substitution energies for $\mathrm{B}$ replacing the sublayer hexa- and tetracoordinated $\mathrm{Al}$ atoms are 4.34 and $2.89 \mathrm{eV}$, respectively, versus 0.81 and $0.57 \mathrm{eV}$ for $\mathrm{Ga}$, which are larger than the substitution energies for $\mathrm{Al}$ substitution on the surface. It indicates that the substitution reaction should favor happening on the surface, rather than in the bulk. In addition, the substitution of tetrahedral Al sites is always more thermodynamically favored than the substitution of octahedral $\mathrm{Al}$ sites.

As reported in the previous work [10], the substitution of $\gamma$-alumina surface Al by $\mathrm{Fe}$ atoms is thermodynamically favored, as the substitution energy for the substitution of all surfaces $\mathrm{Al}$ by $\mathrm{Fe}$ atom is $-0.87 \mathrm{eV}$. It indicates that the $\mathrm{Fe}$ should be more easily to be incorporated into the $\gamma$-alumina than $\mathrm{B}$ and $\mathrm{Ga}$.

3.2. Adsorption of Water Molecules on the $\mathrm{X}_{2} \mathrm{O}_{3}{ }^{*}$ Surfaces (X $=B, A l, G a)$. Figure 3 shows the structures and adsorption 


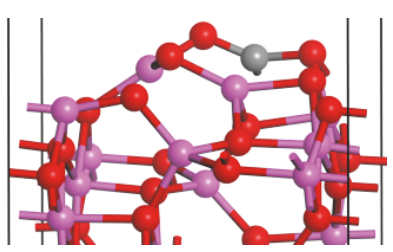

$\mathrm{B}(1)$

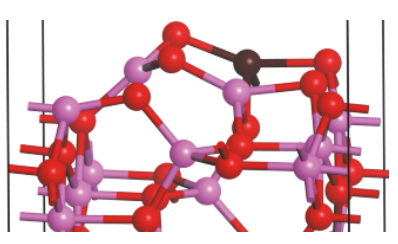

$\mathrm{Ga}(1)$

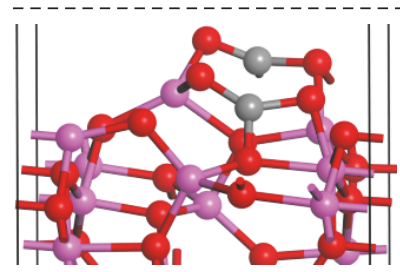

$\mathrm{B}(1,2)$

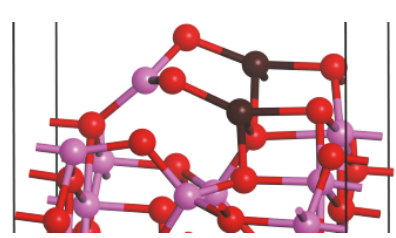

$\mathrm{Ga}(1,2)$

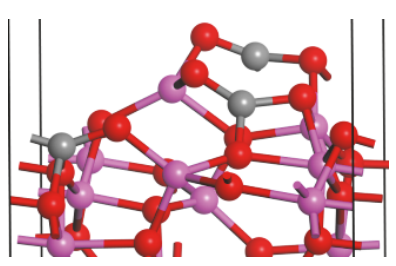

$\mathrm{B}(1,2,3)$

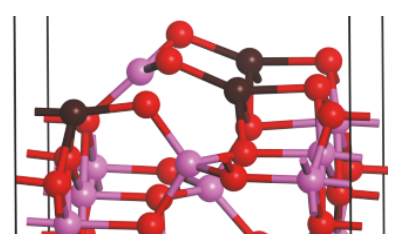

$\mathrm{Ga}(1,2,3)$

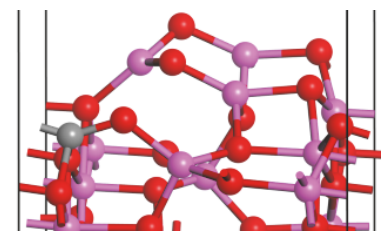

$\mathrm{B}(3)$

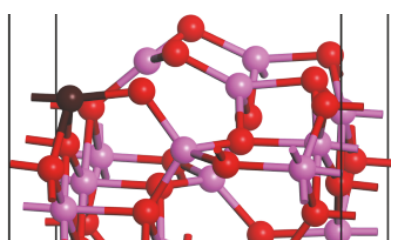

$\mathrm{Ga}(3)$

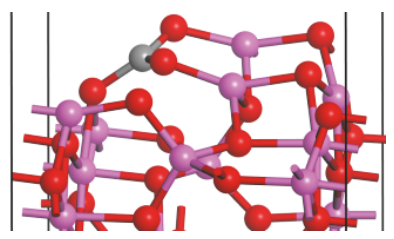

$\mathrm{B}(4)$

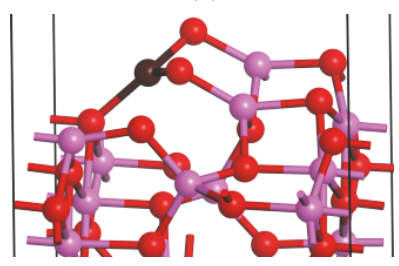

$\mathrm{Ga}(4)$

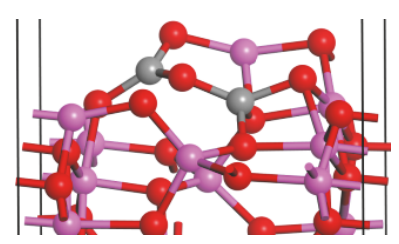

$\mathrm{B}(2,4)$

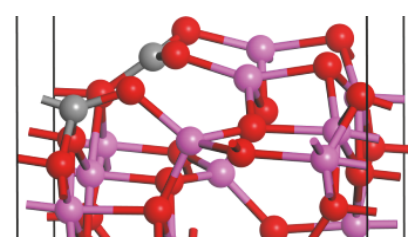

$\mathrm{B}(3,4)$

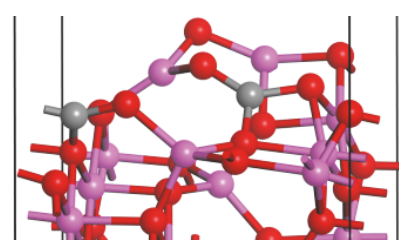

$\mathrm{B}(2,3)$

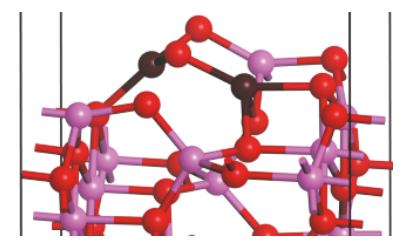

$\mathrm{Ga}(2,4)$

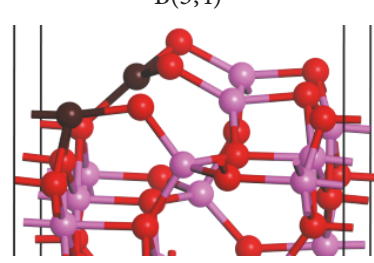

$\mathrm{Ga}(3,4)$

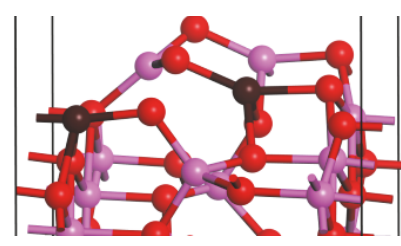

$\mathrm{Ga}(2,3)$

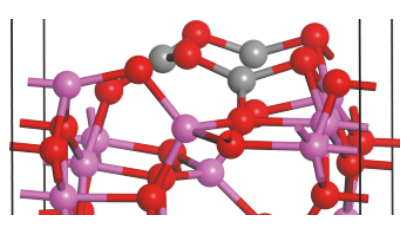

$\mathrm{B}(1,2,4)$

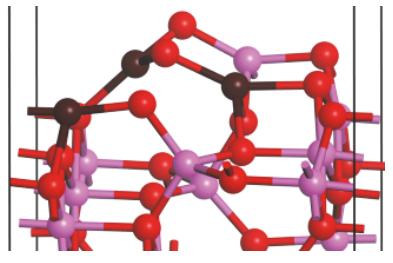

$\mathrm{Ga}(2,3,4)$

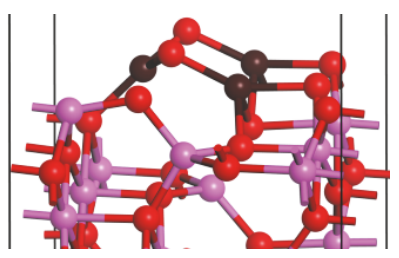

$\mathrm{Ga}(1,2,4)$

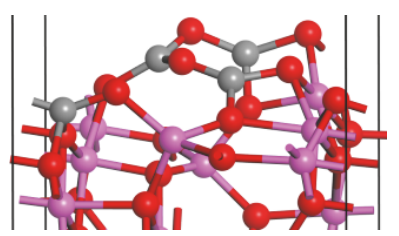

$\mathrm{B}(1,2,3,4)$

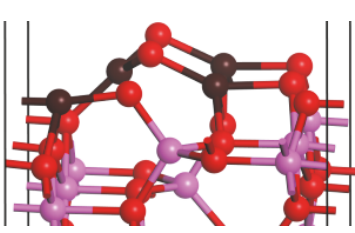

$\mathrm{Ga}(1,2,3,4)$

FIGURE 2: Side views of the $\mathrm{B}$ and $\mathrm{Ga}$ substituted $\gamma-\mathrm{Al}_{2} \mathrm{O}_{3}(110)$ surface (B, $\mathrm{Al}, \mathrm{Ga}$, and $\mathrm{O}$ atoms are in gray, rose, dark, and red, resp.). All figures are indexed corresponding to Table 1. 


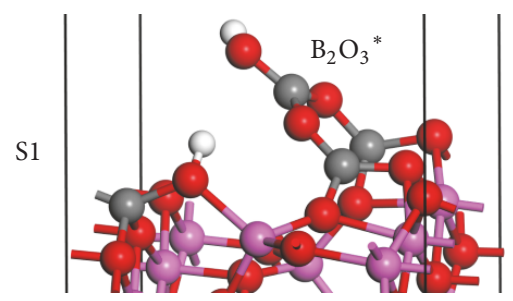

$-3.33$

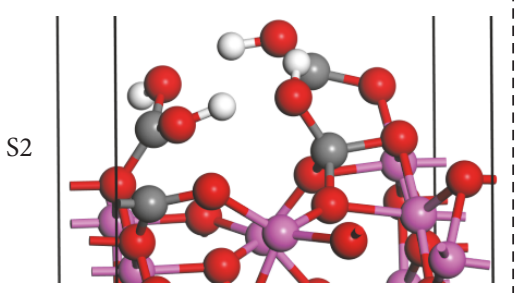

$-4.83,-1.51$

S3

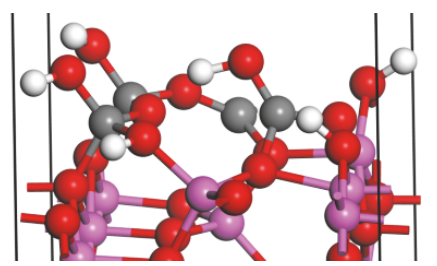

$-6.31,-1.48$

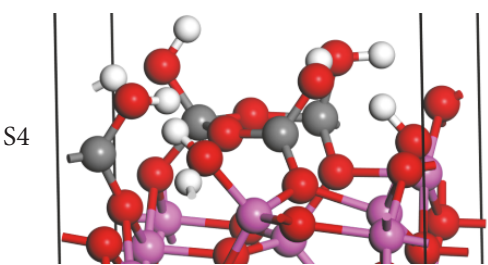

$-6.43,-0.12$

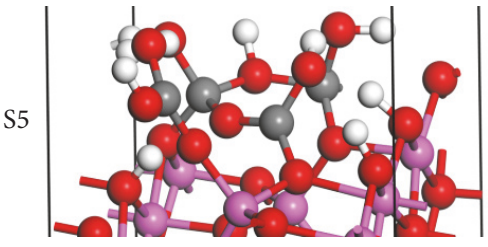

$-8.07,-1.65$

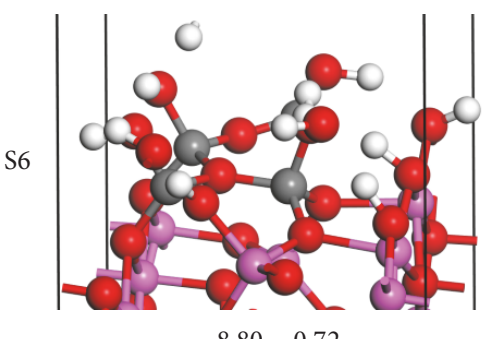

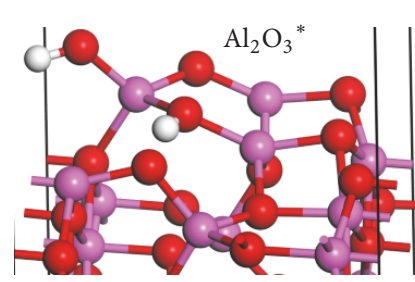

$-2.62$

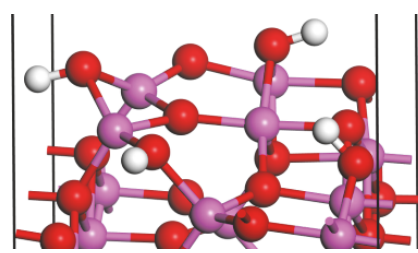

$-4.87,-2.25$

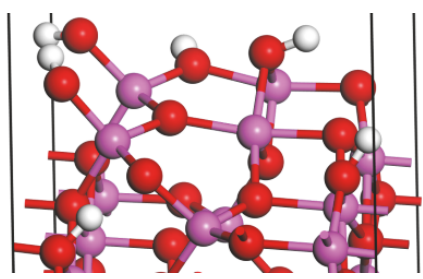

$-6.84,-1.97$

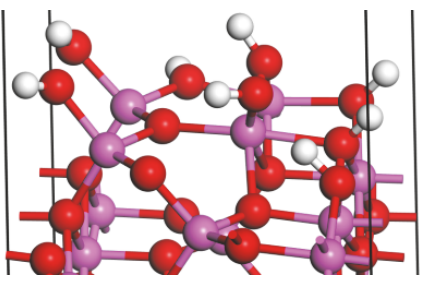

$-8.42,-1.58$

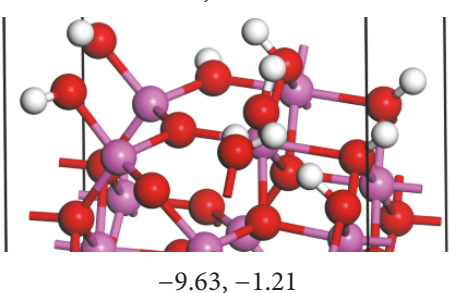

$-9.63,-1.21$

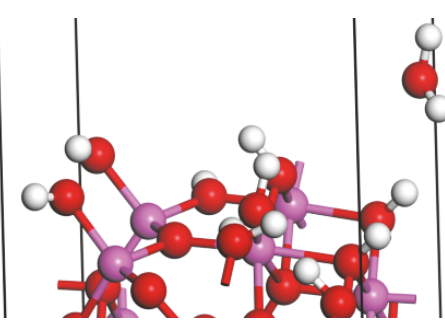

$-10.50,-0.86$

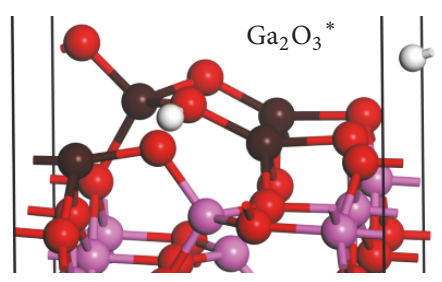

$-1.99$

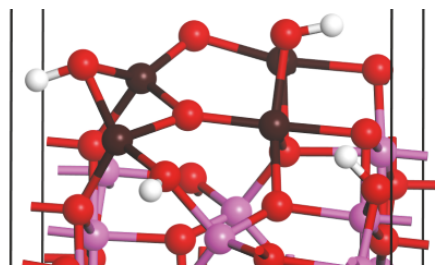

$-4.03,-2.04$

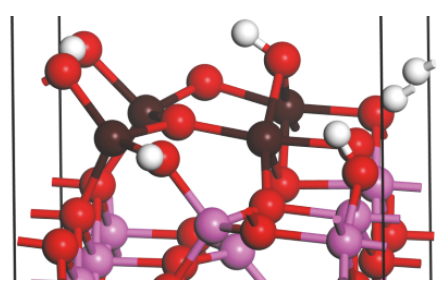

$-5.92,-1.89$

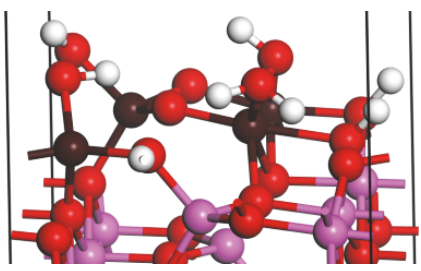

$-6.79,-0.87$

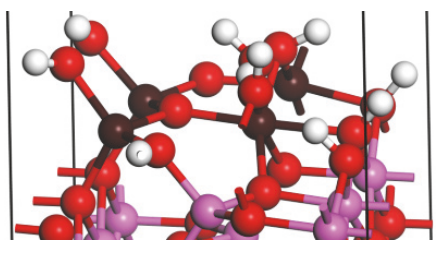

$-8.40,-1.61$

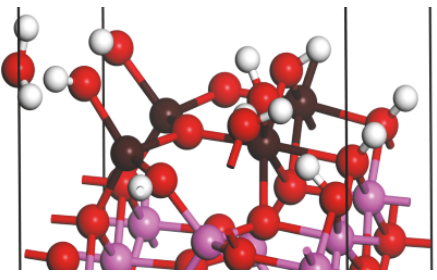

$-9.15,-0.75$

Figure 3: Side views for subsequent water adsorption on $\mathrm{B}_{2} \mathrm{O}_{3}{ }^{*}, \mathrm{Al}_{2} \mathrm{O}_{3}{ }^{*}$, and $\mathrm{Ga}_{2} \mathrm{O}_{3}{ }^{*}$ surfaces, $\mathrm{S} n(n=1-6)$. The total and (subsequent) adsorption energies are given in $\mathrm{eV}$. (B, $\mathrm{Al}, \mathrm{Ga}, \mathrm{O}$, and $\mathrm{H}$ atoms are in gray, rose, dark, red, and white, resp.). 
energies for water adsorption on the $\mathrm{B}_{2} \mathrm{O}_{3}{ }^{*}, \mathrm{Al}_{2} \mathrm{O}_{3}{ }^{*}$, and $\mathrm{Ga}_{2} \mathrm{O}_{3}{ }^{*}$ surfaces. It should be noted that our calculated adsorption energies for the water adsorption on the $\mathrm{Al}_{2} \mathrm{O}_{3}{ }^{*}$ surfaces are $-2.62,-4.87,-6.84,-8.42,-9.63$, and $-10.50 \mathrm{eV}$, respectively, for 1-6 water molecules adsorbed on the $\gamma$ alumina surface. The stepwise adsorption energies for each water molecule are $-2.62,-2.25,-1.97,-1.58,-1.21$, and $-0.86 \mathrm{eV}$. The previous works reported the adsorption of one water molecule on the $\gamma$-alumina (110) surface releases the energy of $-2.49 \mathrm{eV}[1,32]$, which is slightly smaller than the results of present work $(-2.62 \mathrm{eV})$. The reason is that the PBE-D3 methods were used in the present work and dispersion correction effects were taken into consideration. The optimized structures for the adsorption are the same as the previous works. The $\mathrm{Al}_{2} \mathrm{O}_{3}{ }^{*}$ and $\mathrm{Ga}_{2} \mathrm{O}_{3}{ }^{*}$ show similar structures with one $-\mathrm{OH}$ group on the tricoordinated surface $\mathrm{Al} / \mathrm{Ga}$ atom, and $\mathrm{H}$ atom bonds to the twofold coordinated surface $\mathrm{O}$ atoms. It is interesting to see that the surface $\mathrm{B}-\mathrm{O}$ bond was broken after water adsorption, and the âĂŠOH group from the water bonds to the surface $\mathrm{BO}_{2}$ in coplanar. The $\mathrm{H}$ atom from the water adsorbs onto the surface of $\mathrm{O}$ atom forming an in-surface hydroxyl. It leads to a larger adsorption energy for the first water molecule adsorbed on the surface of $\mathrm{B}_{2} \mathrm{O}_{3}{ }^{*}$ than that of $\mathrm{Al}_{2} \mathrm{O}_{3}{ }^{*}$ and $\mathrm{Ga}_{2} \mathrm{O}_{3}{ }^{*}$.

For two water molecules adsorption on the $\mathrm{B}_{2} \mathrm{O}_{3}{ }^{*}$, $\mathrm{Al}_{2} \mathrm{O}_{3}{ }^{*}$, and $\mathrm{Ga}_{2} \mathrm{O}_{3}{ }^{*}$ surfaces, the adsorption energies are $-4.83,-4.87$, and $-4.03 \mathrm{eV}$, respectively. $\mathrm{Al}_{2} \mathrm{O}_{3}{ }^{*}$ shows the largest adsorption energy. The second water molecule makes the $\mathrm{B}_{2} \mathrm{O}_{3}{ }^{*}, \mathrm{Al}_{2} \mathrm{O}_{3}{ }^{*}$, and $\mathrm{Ga}_{2} \mathrm{O}_{3}{ }^{*}$ surfaces seriously distorted. As shown in Figure 3, the $\mathrm{X}(3)$ atom moves to surface $\mathrm{X}(4)$ atom for $\mathrm{X}=\mathrm{Al}$ and $\mathrm{Ga}$, and they share one $-\mathrm{OH}$ group from the water and both became tetracoordinated.

As the water coverage increases from one to six water molecules in one $\mathrm{B}_{2} \mathrm{O}_{3}{ }^{*}$ slab, the adsorption energy increases from $-3.33,-4.83,-6.31,-6.43$, and -8.07 to $-8.80 \mathrm{eV}$, respectively. In comparison, the adsorption energy increases from $-1.99,-4.03,-5.92,-6.79$, and -8.40 to $-9.15 \mathrm{eV}$ for $\mathrm{Ga}_{2} \mathrm{O}_{3}{ }^{*}$ surface. Both are smaller than those for the $\mathrm{Al}_{2} \mathrm{O}_{3}{ }^{*}$ surface. It indicates that the pure $\gamma$-alumina surface shows stronger water adsorption than $\mathrm{B}_{2} \mathrm{O}_{3}{ }^{*}$ and $\mathrm{Ga}_{2} \mathrm{O}_{3}{ }^{*}$. It should be noted that the subsequent adsorption monotonously decreases for the water adsorption on $\mathrm{Al}_{2} \mathrm{O}_{3}{ }^{*}$ surface. Since the water adsorption leads to the surface reconstruction, there are the turning points of the stepwise adsorption energy for 4-5 water molecules adsorption for the $\mathrm{B}_{2} \mathrm{O}_{3}{ }^{*}$ and $\mathrm{Ga}_{2} \mathrm{O}_{3}{ }^{*}$ slabs. In addition, the stepwise adsorption energy for the sixth water molecule adsorbent on the $\mathrm{B}_{2} \mathrm{O}_{3}{ }^{*}, \mathrm{Al}_{2} \mathrm{O}_{3}{ }^{*}$, and $\mathrm{Ga}_{2} \mathrm{O}_{3}{ }^{*}$ surfaces is similar $(-0.72,-0.86$, and $-0.75 \mathrm{eV}$, resp.). The main reason is that the former five water molecules have totally covered the active sites for water adsorption, and the sixth water molecule could only be physically adsorbed.

\section{Conclusions}

The dispersion corrected periodic density functional theory was used to investigate the structure and energies for the B and $\mathrm{Ga}$ incorporated $\gamma$-alumina surface. The results show that the substitution of Al by B is not thermodynamically favored on the surface. However, the substitution of Al by Ga is thermodynamically favored at low coverage on the surface. The substitution reaction prefers to occur at the tricoordinated A(4) sites. The substitution reaction becomes thermodynamically not favored as more and more B and Ga substitutions take place on the surface. The substitutions of Al by B and Ga are not so favored in the bulk as that for the surface.

The adsorption of water molecules on the $\mathrm{B}$ and $\mathrm{Ga}$ incorporated $\gamma$-alumina surface was also investigated and compared to that of the pure $\gamma$-alumina surface. It shows that the $\gamma$-alumina surface has the strongest adsorption ability for water adsorption. The total adsorption energy increases as water coverage increases from one to six water molecules in each slab, while the stepwise adsorption energy decreases. On the $\mathrm{B}_{2} \mathrm{O}_{3}{ }^{*}, \mathrm{Al}_{2} \mathrm{O}_{3}{ }^{*}$, and $\mathrm{Ga}_{2} \mathrm{O}_{3}{ }^{*}$ surfaces, the sixth could only be physically adsorbed on the surface, since the former adsorbed five water molecules (at the coverage of 7.5 $\mathrm{H}_{2} \mathrm{O} / \mathrm{nm}^{2}$ ) fully covered the active sites for water adsorption.

\section{Conflicts of Interest}

The authors declare that there are no conflicts of interest regarding the publication of this paper.

\section{Acknowledgments}

This work was supported by the Doctoral Scientific Research Foundation for Dr. Lihong Cheng of Jiangxi Science \& Technology Normal University (2017.1-2020.12), Science Foundation of Jiangxi Department of Education (GJJ150827), and National Natural Science Foundation of Jiangxi Province (20151BAB204009).

\section{References}

[1] G. Feng, C.-F. Huo, C.-M. Deng et al., "Isopropanol adsorption on $\gamma-\mathrm{Al}_{2} \mathrm{O}_{3}$ surfaces: a computational study," Journal of Molecular Catalysis A: Chemical, vol. 304, no. 1-2, pp. 58-64, 2009.

[2] L. Huang, Y.-L. Zhu, C.-F. Huo et al., "Mechanistic insight into the heterogeneous catalytic transfer hydrogenation over $\mathrm{Cu} / \mathrm{Al}_{2} \mathrm{O}_{3}$ : direct evidence for the assistant role of support," Journal of Molecular Catalysis A: Chemical, vol. 288, no. 1-2, pp. 109-115, 2008.

[3] Y. Liu, J. Liu, G. Feng, S. Yin, W. Cen, and Y. Liu, "Interface effects for the hydrogenation of $\mathrm{CO}_{2}$ on $\mathrm{Pt}_{4} / \gamma-\mathrm{Al}_{2} \mathrm{O}_{3}$," Applied Surface Science, vol. 386, pp. 196-201, 2016.

[4] B. Ealet, M. H. Elyakhloufi, E. Gillet, and M. Ricci, "Electronic and crystallographic structure of $\gamma$-alumina thin films," Thin Solid Films, vol. 250, no. 1-2, pp. 92-100, 1994.

[5] J. Libuda, F. Winkelmann, M. Bäumer et al., "Structure and defects of an ordered alumina film on $\mathrm{NiAl}(110)$," Surface Science, vol. 318, no. 1-2, pp. 61-73, 1994.

[6] D. W. Susnitzky and C. B. Carter, "The formation of copper aluminate by solid-state reaction," Journal of Materials Research, vol. 6, no. 9, pp. 1958-1963, 1991.

[7] G. A. El-Shobaky, N. M. Ghoneim, and E. A. Sultan, "Thermal decomposition of nickel aluminium mixed hydroxides and formation of nickel aluminate spinel," Thermochimica Acta, vol. 63, no. 1, pp. 39-49, 1983. 
[8] T. Wang, F. Jiang, G. Liu, L. Zeng, Z.-J. Zhao, and J. Gong, "Effects of $\mathrm{Ga}$ doping on $\mathrm{Pt} / \mathrm{CeO}_{2}-\mathrm{Al}_{2} \mathrm{O}_{3}$ catalysts for propane dehydrogenation," AIChE Journal, vol. 62, no. 12, pp. 4365-4376, 2016.

[9] B. Bonnetot, V. Rakic, T. Yuzhakova et al., "Preparation and characterization of $\mathrm{Me}_{2} \mathrm{O}_{3}-\mathrm{CeO}_{2}(\mathrm{Me}=\mathrm{B}, \mathrm{Al}, \mathrm{Ga}$, In) mixed oxide catalysts. 2. Preparation by sol-gel method," Chemistry of Materials, vol. 20, no. 4, pp. 1585-1596, 2008.

[10] G. Feng, C.-F. Huo, Y.-W. Li, J. Wang, and H. Jiao, "Structures and energies of iron promoted $\gamma-\mathrm{Al}_{2} \mathrm{O}_{3}$ surface: a computational study," Chemical Physics Letters, vol. 510, no. 4-6, pp. 224-227, 2011.

[11] H.-J. Wan, B.-S. Wu, C.-H. Zhang et al., "Study on $\mathrm{Fe}-\mathrm{Al}_{2} \mathrm{O}_{3}$ interaction over precipitated iron catalyst for Fischer-Tropsch synthesis," Catalysis Communications, vol. 8, no. 10, pp. 15381545, 2007.

[12] V. G. De Resende, X. Hui, C. Laurent, A. Weibel, E. De Grave, and A. Peigney, "Fe-substituted mullite powders for the in situ synthesis of carbon nanotubes by catalytic chemical vapor deposition," Journal of Physical Chemistry C, vol. 113, no. 26, pp. 11239-11245, 2009.

[13] V. G. de Resende, A. Cordier, E. De Grave et al., "Synthesis of $\gamma$ - $\left(\mathrm{Al}_{1-x} \mathrm{Fe}_{x}\right)_{2} \mathrm{O}_{3}$ solid solutions from oxinate precursors and formation of carbon nanotubes from the solid solutions using methane or ethylene as carbon source," Journal of Materials Research, vol. 23, no. 11, pp. 3096-3111, 2008.

[14] V. G. de Resende, A. Cordier, E. de Grave et al., "Presence of metallic Fe nanoclusters in $\alpha$ - $(\mathrm{Al}, \mathrm{Fe})_{2} \mathrm{O}_{3}$ solid solutions," The Journal of Physical Chemistry C, vol. 112, no. 42, pp. 16256-16263, 2008.

[15] G. Feng, D. Yang, D. Kong, J. Liu, and Z.-H. Lu, "A comparative computational study on the synthesis prescriptions, structures and acid properties of B-, Al- and G-incorporated MTW-type zeolites," RSC Advances, vol. 4, no. 89, pp. 47906-47920, 2014.

[16] J. Zhou, J. Teng, L. Ren et al., "Full-crystalline hierarchical monolithic ZSM-5 zeolites as superiorly active and long-lived practical catalysts in methanol-to-hydrocarbons reaction," Journal of Catalysis, vol. 340, pp. 166-176, 2016.

[17] C. G. Zuo, A. G. Xiao, Z. H. Zhou et al., "Spectroscopic properties of $\mathrm{Ce}^{3+}$-doped $\mathrm{BaO}-\mathrm{Gd}_{2} \mathrm{O}_{3}-\mathrm{Al}_{2} \mathrm{O}_{3}-\mathrm{B}_{2} \mathrm{O}_{3}-\mathrm{SiO}_{2}$ glasses," Journal of Non-Crystalline Solids, vol. 452, pp. 35-39, 2016.

[18] V. A. Silva, P. C. Morais, R. F. Morais, and N. O. Dantas, "Successful Nd" doping of $\mathrm{Li}_{2} \mathrm{O}-\mathrm{B}_{2} \mathrm{O}_{3}-\mathrm{Al}_{2} \mathrm{O}_{3}$ vitreous system: optical characterization and judd-ofelt spectroscopic calculations," Brazilian Journal of Physics, vol. 46, no. 6, pp. 643-648, 2016.

[19] J. L. Jansons, P. A. Kulis, Z. A. Rachko et al., "Luminescence of Ga-doped alpha- $\mathrm{Al}_{2} \mathrm{O}_{3}$ crystals," Physica Status Solidi B-Basic Research, vol. 120, no. 2, pp. 511-518, 1983.

[20] M. E. Kibar, O. Özcan, Y. Dusova-Teke, E. Yonel-Gumruk, and A. N. Akin, "Optimization, modeling and characterization of sol-gel process parameters for the synthesis of nanostructured boron doped alumina catalyst supports," Microporous and Mesoporous Materials, vol. 229, pp. 134-144, 2016.

[21] J. P. Perdew, K. Burke, and M. Ernzerhof, "Generalized gradient approximation made simple," Physical Review Letters, vol. 77, no. 18, pp. 3865-3868, 1996.

[22] G. Kresse and J. Furthmüller, "Efficiency of ab-initio total energy calculations for metals and semiconductors using a plane-wave basis set," Computational Materials Science, vol. 6, no. 1, pp. 15-50, 1996.
[23] G. Kresse and J. Furthmüller, "Efficient iterative schemes for ab initio total-energy calculations using a plane-wave basis set," Physical Review B - Condensed Matter and Materials Physics, vol. 54, no. 16, pp. 11169-11186, 1996.

[24] J. Liu, Z.-F. Liu, G. Feng, and D. Kong, "Dimerization of propene catalyzed by Brønsted acid sites inside the main channel of zeolite SAPO-5: a computational study," The Journal of Physical Chemistry C, vol. 118, no. 32, pp. 18496-18504, 2014.

[25] G. Feng, Y.-Y. Lian, D. Yang, J. Liu, and D. Kong, “Distribution of $\mathrm{Al}$ and adsorption of $\mathrm{NH}_{3}$ and pyridine in ZSM-12: a computational study," Canadian Journal of Chemistry, vol. 91, no. 10, pp. 925-934, 2013.

[26] S. Grimme, A. Hansen, J. G. Brandenburg, and C. Bannwarth, "Dispersion-corrected mean-field electronic structure methods," Chemical Reviews, vol. 116, no. 9, pp. 5105-5154, 2016.

[27] S. Grimme, S. Ehrlich, and L. Goerigk, "Effect of the damping function in dispersion corrected density functional theory," Journal of Computational Chemistry, vol. 32, no. 7, pp. 14561465, 2011.

[28] S. Grimme, J. Antony, S. Ehrlich, and H. Krieg, "A consistent and accurate $\mathrm{ab}$ initio parametrization of density functional dispersion correction (DFT-D) for the 94 elements H-Pu," Journal of Chemical Physics, vol. 132, no. 15, Article ID 154104, 2010.

[29] G. Kresse and D. Joubert, "From ultrasoft pseudopotentials to the projector augmented-wave method," Physical Review B, vol. 59, no. 3, pp. 1758-1775, 1999.

[30] P. E. Blöchl, C. J. Först, and J. Schimpl, "Projector augmented wave method: ab initio molecular dynamics with full wave functions," Bulletin of Materials Science, vol. 26, no. 1, pp. 3341, 2003.

[31] P. E. Blöchl, "Projector augmented-wave method," Physical Review B, vol. 50, no. 24, pp. 17953-17979, 1994.

[32] M. Digne, P. Sautet, P. Raybaud, P. Euzen, and H. Toulhoat, "Use of DFT to achieve a rational understanding of acid-basic properties of $\gamma$-alumina surfaces," Journal of Catalysis, vol. 226, no. 1, pp. 54-68, 2004.

[33] J. Wang, H. Yu, L. Geng et al., "DFT Study of Hg Adsorption on M-substituted $\mathrm{Pd}(111)$ and $\mathrm{PdM} / \gamma-\mathrm{Al}_{2} \mathrm{O}_{3}(110)(\mathrm{M}=\mathrm{Au}, \mathrm{Ag}, \mathrm{Cu})$ Surfaces," Applied Surface Science, vol. 355, pp. 902-911, 2015.

[34] L. Geng, L. Han, W. Cen et al., "A first-principles study of $\mathrm{Hg}$ adsorption on $\mathrm{Pd}(111)$ and $\mathrm{Pd} / \gamma-\mathrm{Al}_{2} \mathrm{O}_{3}(110)$ surfaces," Applied Surface Science, vol. 321, pp. 30-37, 2014.

[35] B. Cordero, V. Gómez, A. E. Platero-Prats et al., "Covalent radii revisited," Dalton Transactions, no. 21, pp. 2832-2838, 2008. 

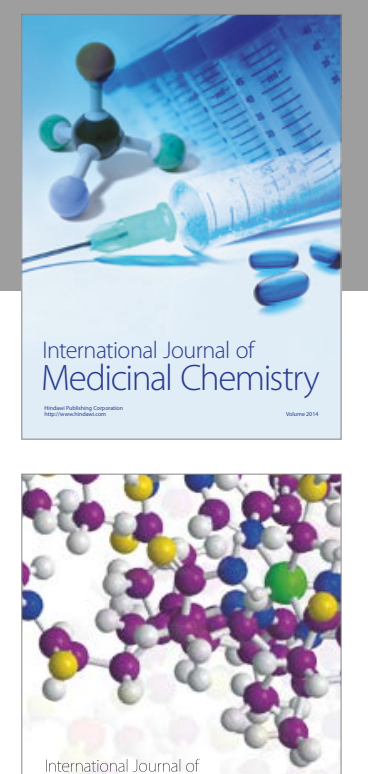

Carbohydrate Chemistry

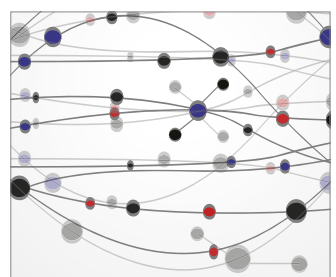

The Scientific World Journal
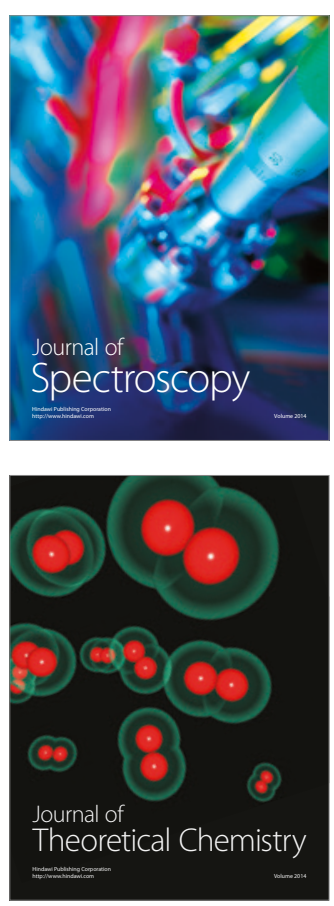
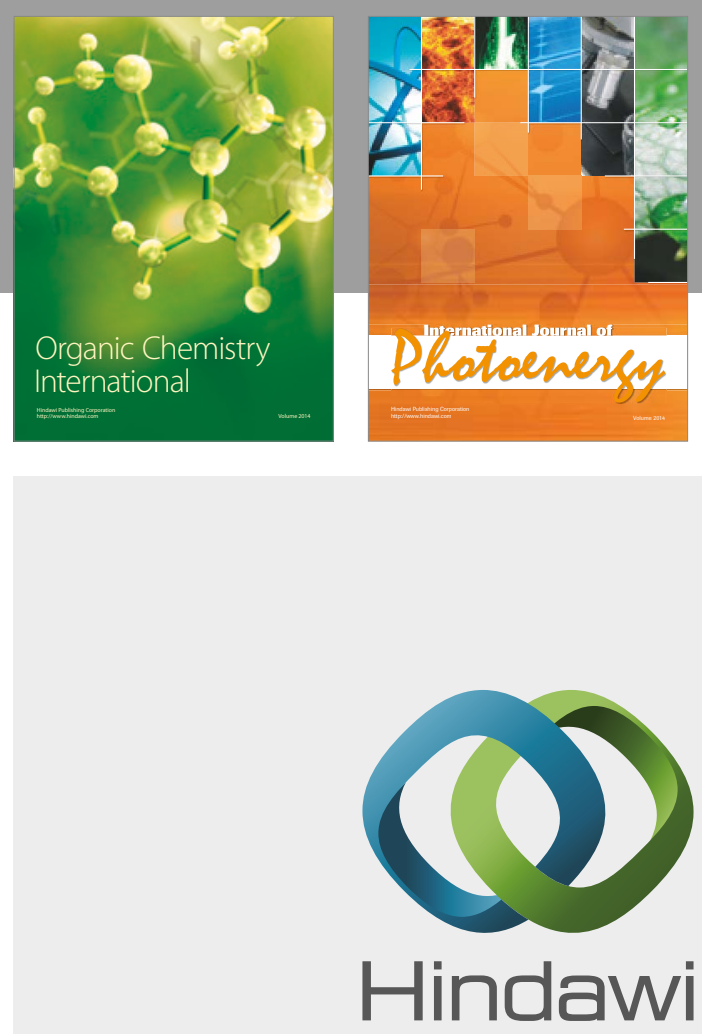

Submit your manuscripts at

https://www.hindawi.com

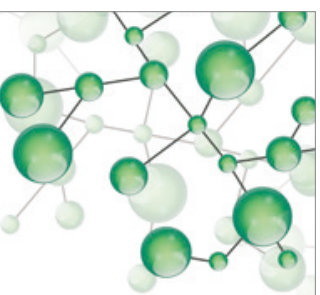

International Journal of

Inorganic Chemistry

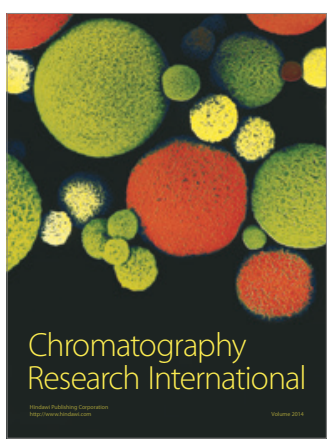

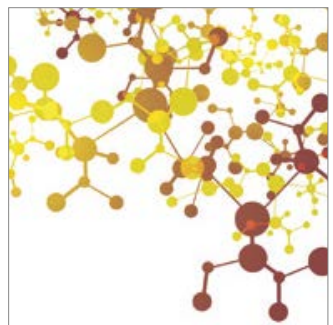

Applied Chemistry
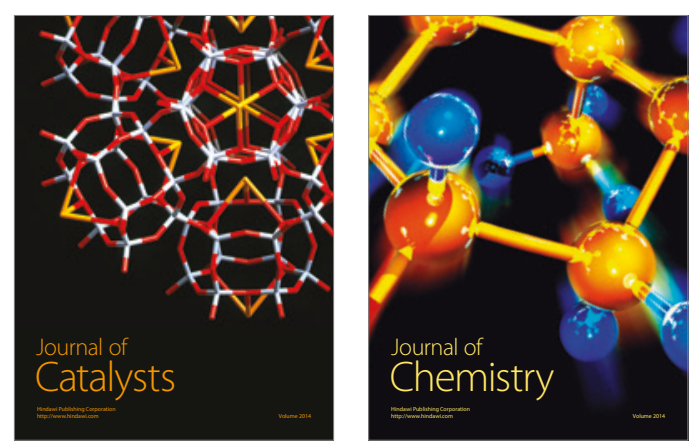
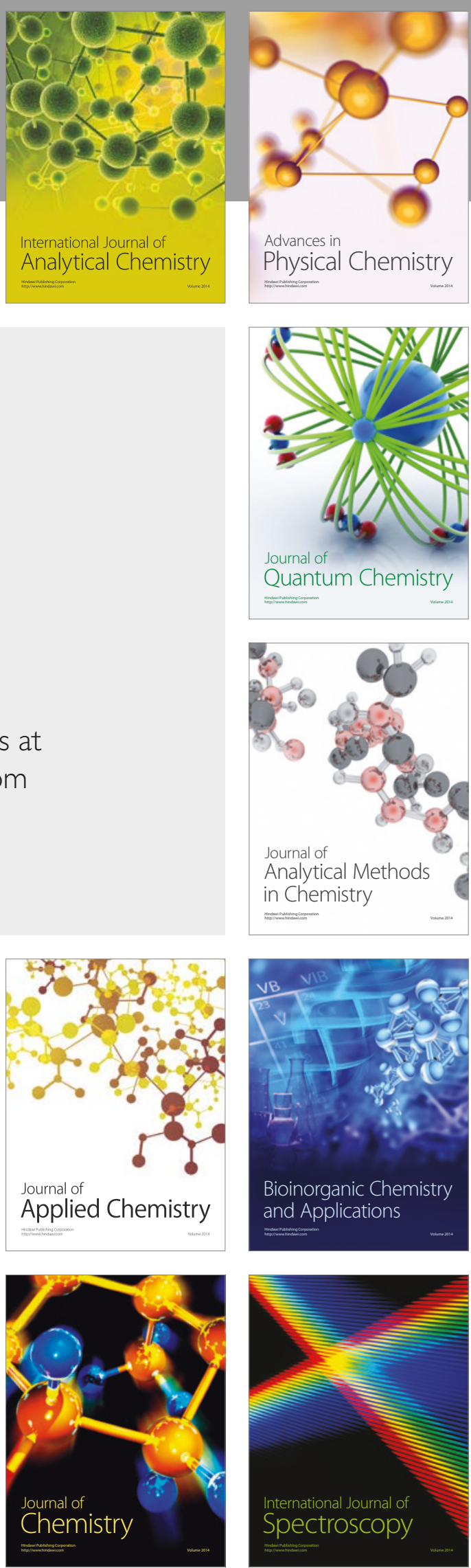